\title{
The Application and Enlightenment of Second Language Acquisition Theory in English Teaching
}

\author{
Lu Liu \\ Xi'an University 710065
}

Keywords: Second language acquisition; Theory; English teaching

\begin{abstract}
The second language acquisition theory has a great guiding effect on English teaching. In English teaching, the application of second language acquisition can enable students to study in the English language environment, and thus improve the quality of English classroom teaching. In this study, according to the use of second language acquisition theory in the classroom, the application research is performed to optimize English teaching.
\end{abstract}

\section{Introduction}

Language is the carrier of interpersonal communication. The ultimate goal of learning language is to use this carrier to communicate. English classroom teaching is one of the important ways to learn language. Therefore, English classroom teaching should be given high attention. However, the language learning is not an overnight thing, but a complex process. How to use limited English classroom to improve students' English ability has become the main problem of English teaching.

\section{Relevant Explanations of Second Language Acquisition Theory}

According to the second language acquisition process and its rule, scholars put forward the theories of second language acquisition. Although these theories cannot directly solve the problems in English teaching, they have some inspirations and important guiding significance for English teaching. Since the 1970s, many scholars have studied the second language acquisition from different angles. In the past 30 years, the second language acquisition theories have emerged in endlessly. Among them, Chomsky's Theory of Second Language Acquisition theory and Krashen's Theory of Second Language Acquisition are popular second language acquisition theories in academia.

Chomsky's Theory of Second Language Acquisition. Chomsky's Theory of Second Language Acquisition clearly states that language knowledge is innate and that language is determined by the human genetic. Chomsky put forward the universal grammar theory. He believes that innate language knowledge is "universal grammar." In a person's gene, if there is no genetic aspect of language, we will say that he has no language talent, and then this person won't be successful either in learning the mother tongue or the second language. The main reason for the failure is that in the process of language learning, his language input is not sufficient, seriously affected the second language acquisition. Chomsky believes that language is the main expression form of human activities. Learning language and language communication ability is born with us. In infancy, our language may have a lot of mistakes, but this does not require us to correct, because with the continuous growth and accumulation of practical experience, these errors will be slowly amended. When we learn a second language, many people often regard grammar learning as the main evaluation criterion for language learning. The purpose is to ensure that there is no error in communication, but this process is too rigid. As we accumulate more and more language knowledge, the continuous improvement of the knowledge level, the use of language will become more and more flexible. In other words, simply learning language from the textbook is not enough. Language acquisition can be valid only through the effective language input.

Krashen's Theory of Second Language Acquisition. American linguist Krashen proposed a complete second language acquisition model for the second language acquisition process, which provides an important theoretical basis for English teaching. This model mainly includes five 
hypotheses: the acquisition learning hypothesis, the input hypothesis, the affective filter hypothesis, the natural order hypothesis and the monitor hypothesis. Krashen expresses the relationship between these five hypotheses and the second language as: language input $\rightarrow$ affective filter $\rightarrow$ language acquisition mechanism $\rightarrow$ acquisition of language skills $\rightarrow$ language output. He believes that language acquisition is different from language learning. Language acquisition is obtained from the language use in the natural communication scene through contacting language context and gaining the understanding of discourses. The input hypothesis is the core content of the second language acquisition theory. Krashen argues that the necessary condition for language acquisition is "comprehensible language Input ", and input materials and input methods have a significant effect on the outcome and quality of affective filter. Krashen believes that language acquisition and learning hypothesis are two processes involved in second language acquisition. The learning process refers to the conscious understanding and digestion of the second language. The acquisition means to operate and apply the second language practically in the unconscious process, and simultaneously enhance comprehension and digestion. Krashen insists that "acquisition" is more important than "learning". In addition to language acquisition and learning hypothesis, language input hypothesis and affective filter hypothesis also have a particularly important significance on modern English teaching.

Language Input Hypothesis. Language input hypothesis is the core part of Krashen's Theory of Second Language Acquisition, which clearly states that sufficient language input can improve the second language ability. Language input refers to the input of the language that the learner can understand. Only by receiving a rich and understandable language input can the learner enhance his second language ability. The so-called language input cannot be either too difficult or too easy for the learners so that they can understand and digest. Whether the language input is too difficult or too easy will affect the learners to receive the language input. That is to say, the learner cannot receive the language input in line with their own. Krashen believes: Firstly, the language input must be understandable, because the acquisition will not happen if the learner cannot receive the language input in line with their own. The learner is able to receive new knowledge on the basis of his own second language knowledge only if he receives a language input that is slightly stronger than his second language level. Secondly, the language input has a requirement of quantity, so there must be a lot of language input. Language learners are able to receive a large number of language input only in the appropriate language environment, imperceptibly forming language awareness. Thirdly, language input requires interest and relevance. Different from the traditional reading and writing, language input needs to have a high degree of interesting and relevance so that language learners can receive language input with a good attitude. Fourthly, the traditional language input pay much emphasis on grammar learning, which makes that the information received by the language learner is too mechanized, but Krashen language input does not pay attention to the acquisition of grammar order, so that language acquisition will not appear mechanization, and nor contrary to the theory of acquisition.

The Affective Filter Hypothesis. Krashen argues that affective filter also plays a very important role in second language acquisition. He explains the reason why the second language learner has a different learning speed and language level for the second language, that is, the relationship between the affective factors and the second language acquisition. When learning the second language, the learners will carry out affective filter on the language input; these affections refer to the learning motivation, anxiety, and self-confidence and so on. If the second language learner does not have a strong motivation to learn, has a strong sense of anxiety, and has no self-confidence in learning, it will all have a strong role in the language filter, which leads to very few language input of second language acquisition. On the contrary, if learners can reduce the affective filter effect of the second language, it will get sufficient and effective language input, thus enhancing the effectiveness of their own language learning.

\section{The Current Situation of English Classroom Teaching in China}

To study the application of second language acquisition theory in English teaching in China, we 
must first analyze the present situation of English teaching in our country. This paper mainly analyzes the present situation of English classroom teaching from the following aspects.

Simple Teaching Content Leading to the Derailment of Reality. In the current English teaching, the traditional model of teacher lecturing and students listening to is still used. The teacher is in a dominant position in the English classroom. The entire English classroom gives priority to with the teacher's teaching, completely ignored the students' main role, and the students just recite words, grammar, etc. mechanically. The result of this kind of spoon-fed teaching is that students can deal with a variety of examinations, but the teacher has completely ignored the exertion of students' acquisition ability. This mechanical, rigid language input pattern seriously undermines the interest and relevance of the student's language learning. The entire teaching process ignores the main role of students, which causes the variety of English practical and applying ability of the students to get no cultivation. Although the students' test scores are very satisfactory, students do not understand English and cannot speak in the actual use of language occasions, which is completely derailed with the real life. This is contrary to Krashen's Theory of Second Language Acquisition and modern teaching philosophy.

Backward Teaching Mode and Teaching Methods. Under the influence of the environment of the examination-oriented education, English teaching mainly focuses on the examination. Teaching for teachers and learning for students are all for the examination. Teachers and students believe that grammar and words are the main contents of English learning. Teachers and students only teach and learn in a mechanical way. In English teaching, teachers only teach English knowledge, but pay less attention to the popularity and application of modern education technologies which can enhance students' learning interest, create teaching situation and improve students' English language sense, and do not ameliorate the teaching mode and teaching method timely. Mechanical purpose for examination and mechanical language input has greatly influenced students' affective filter of second language input.

Negligence of the Affective Filter Elimination. Many English learners have not yet fully formed clear English learning ideas and goals, and have not found a learning method suitable for them. There are also many English learners who are very clear about the importance of English on their own and have a high enthusiasm for English learning. However, they are not confident enough to learn English feel very anxious, which to a large extent, aggravates the affective filter of students' language input. In this case, however, English teachers do not help students eliminate the affective filter timely and actively.

Slow Update of Teaching Materials and Limited Examination Contents. The society develops rapidly, but the English teaching materials have not been updated timely. Slow update of English materials cannot make English teaching meet the needs of the social development. In addition, English test contents have great limitations, which make students copy and paste the test contents, just like a machine. In order to obtain excellent test scores, students will blindly obey, completely ignoring the innovation and autonomy. These problems seriously affect the English language input, making the language input boring and the English learning goals distorted, eventually leading to invalid exercise and exertion of English practical ability, either cannot adapt to society and the needs of enterprise development.

\section{The Application and Enlightenment of the Second Language Acquisition Theory in English Teaching}

Creating Rich Language Input Plan. English classroom is the main place for students to learn English, which is also the main channel for English teachers to input English to students. English classroom is the main place for teachers and students to communicate. In order to improve students' self-consciousness of language, teachers should create a good classroom learning environment. English teachers should create a language input plan. The complexity of English language input should be chosen according to the students' English level and the second language acquisition characteristics, so as to provide students with appropriate English language knowledge. In the English classroom, English teachers should guide students to correctly deal with the contacted 
language input and promote students of the natural acquisition process of English language by external reinforcement. In English class, English teachers should learn to make full use of modern scientific means and methods, and learn to use modern multimedia teaching tools, such as: TV or movie clips, the main background music, historical images and pictures, so that the English classroom in the language input becomes lively and interesting. Besides, auxiliary demonstration of the correct language input will improve students' interest in English learning, and affective filter of English learning contents will be effectively performed, thus improving students' learning ability in the English class.

Enhancing the Interesting of Language Input. In order to enhance the interest of language input, English teachers should make full use of modern teaching techniques, connect social life, create a rich teaching situation, enhance students' interest and relevance in language input, and fully mobilize students' senses, thus creating a vivid and spot teaching atmosphere and making students learn English in a pleasant atmosphere. This can not only make the English classroom more relaxed and interesting, but also enable students to understand the language input and deepen students' impression.

Promoting the Exertion of Acquisition Ability. Krashen believes that acquisition is more important than learning. Application of Second Language Acquisition Theory to create extracurricular English language environment can make up for the inadequacy of classroom English teaching. Therefore, an English teacher should create a favorable teaching environment for students' second language acquisition in the process of teaching English, making students receive more English language information in the extracurricular English language environment, thus improving students' language knowledge reserves. In the English class, English teachers need to teach basic grammar, vocabulary points and sentence analysis and other language inputs to students, but in the English language input, the external environment is much better than the classroom input, so the English teachers also need to help students acquire a certain social and cultural phenomenon and the ability to read the discourse and create a diversified language environment so that students can perform a language communication practice in a real language environment and imperceptibly acquire English language. For example, English teachers can encourage students to participate in various English-related associations, or make foreign friends to make students learn in the English language environment, and also encourage students to use modern information technologies like computers, mobile phones, etc., to improve students' ability to retain and absorb English language information, so as to make up for the problems of practice time shortage in English classroom. Therefore, English teachers should give full play to the dual effect of classroom teaching and extracurricular learning.

Encouraging Students to Form a Positive and Good Learning Attitude. The key to improve the effectiveness of English teaching is how to stimulate students' enthusiasm for learning. Teachers should teach with humanism. English teachers should not only create a good language learning environment for students, but also fully apply affective factors of language input, that is, using affective factors to input language information, which is mentioned in Krashen's Theory of Second Language Acquisition. English teachers should fully respect the subjectivity of students, mobilize the students' motivation to learn, eliminate the negative emotions of students, and help students establish a correct view of English learning. Therefore, English teachers should provide students with a relaxed and pleasant learning environment. They should go down the podium and establish a harmonious interaction with students to eliminate the tension and anxious psychology of students. Teachers should treat students equally without discrimination, care and respect for each student to enhance their self-confidence in learning English. English teachers should observe the students' emotions in the daily teaching, grasp of the opportunity of English teaching accurately according to the students' own characteristics, thus eliminating students' bad mood and making students more effective to receive language input.

Designing and Writing Suitable English Textbooks. Textbook is very important to second language acquisition theory as its input information is related to whether the students can really understand and is also related to the creation of second language learning environment. Therefore, 
the design of English textbooks must take into account whether the content of teaching materials is close to life, and whether it has relevance with real life. Only in this way, students can more easily receive, understand and master the content of teaching materials. In addition, the textbooks should also be properly integrated into the cultural content of Western countries, such as customs, lifestyles, religious beliefs, thinking habits and so on. Rich and colorful English textbooks can create a good learning atmosphere for students.

At present, Chinese English teachers should make full use of second language acquisition theory and explore the new English teaching model. Teachers should stand on the forefront of English classroom teaching and use second language acquisition theory for innovation of teaching methods to create a relaxed and happy language learning environment for students, thus improving the quality of English classroom and English teaching.

\section{References}

[1] S.D. Krashen: Second Language Acquisition and Second Language Learning (Pergamon Press Ltd., British 1981).

[2] Y.N. Xiao and M.C. Dai: Issues in Applying SLA Findings to Classroom Instruction. Foreign Language World, Vol. 101 (2004) No. 3, p. 32. (In Chinese)

[3] B. Huang: An Introduction to Second Language Acquisition (Guangdong Higher Education Press, China 2004). (In Chinese)

[4] X.W. Zhou: Of Second Language Acquisition for College English Teaching and Learning. Journal of Legends and Biographies, (2010) No. 1, p. 78. (In Chinese)

[5] L. Chen: On the Inspiration of Krashen's Theory of Second Language Acquisition to College English Teaching. Overseas English, (2010) No. 8, p. 17. (In Chinese)

[6] T.Y. Jiang and Q. Liu: How to Improve the Quality of English Classroom Teaching from the Perspective of Second Language Acquisition. Time Education, (2011) No. 4, p. 116. (In Chinese)

[7] D.F. Shu: FLT in China: Problems and Suggested Solutions (Shanghai Foreign Language Education Press, China 2004). (In Chinese)

[8] L.S. Luo and W.X. Zhang: Paying Attention to Practical Teaching and Improving Students' English Application Ability. China High Education, (2002) No. 11, p. 14. (In Chinese)

[9] Z. Li: Study on Second Language Acquisition (Shandong University Press, China 2000). (In Chinese)

[10]X. Cao: Some Suggestions on the Reform of Foreign Language Teaching in Colleges and Universities. Higher Education Forum, (2004) No. 2, p. 123. 